\title{
Scale orientated analysis of river width changes due to extreme flood hazards
}

\author{
G. Krapesch, C. Hauer, and H. Habersack \\ Christian Doppler Laboratory for advanced methods in river monitoring, modelling and engineering, Vienna, Austria
} BOKU University of Natural Resources and Life Sciences, Vienna, Austria

Department of Water, Atmosphere and Environment, Institute of Water Management, Hydrology and Hydraulic Engineering, Muthgasse 107, 1190 Vienna, Austria

Received: 13 August 2010 - Revised: 7 November 2010 - Accepted: 30 November 2010 - Published: 4 August 2011

\begin{abstract}
This paper analyses the morphological effects of extreme floods (recurrence interval $>100$ years) and examines which parameters best describe the width changes due to erosion based on 5 affected alpine gravel bed rivers in Austria. The research was based on vertical aerial photos of the rivers before and after extreme floods, hydrodynamic numerical models and cross sectional measurements supported by LiDAR data of the rivers. Average width ratios (width after/before the flood) were calculated and correlated with different hydraulic parameters (specific stream power, shear stress, flow area, specific discharge). Depending on the geomorphological boundary conditions of the different rivers, a mean width ratio between 1.12 (Lech River) and 3.45 (Trisanna River) was determined on the reach scale. The specific stream power (SSP) best predicted the mean width ratios of the rivers especially on the reach scale and sub reach scale. On the local scale more parameters have to be considered to define the "minimum morphological spatial demand of rivers", which is a crucial parameter for addressing and managing flood hazards and should be used in hazard zone plans and spatial planning.
\end{abstract}

\section{Introduction}

The geomorphic effects of floods are a frequent subject of research in fluvial geomorphology, hydraulic engineering, flood protection and risk management (Gilvear, 1999; Plate, 2002; Yin and Li, 2001; Zielinski, 2003; Magilligan et al., 1998; Cenderelli and Wohl, 2003b; Lapointe et al., 1998; Zimmermann and Church, 2001). Flood hazards

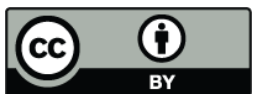

Correspondence to: G. Krapesch (gerald.krapesch@boku.ac.at) substantially affect the morphology of river systems in a very short time period (Hooke, 2008; Neuhold et al., 2009; Miller, 1990). Long term the lateral morphological changes, quantified by comparing the river width before and after the event (Zhang et al., 2009), can be determined as a characteristic feature for various river types (Bertoldi et al., 2010).

Those river width changes during flood hazards depend on multiple processes and boundary conditions. Thus the basic features and constraints such as hydrologic characteristics, channel and valley morphology, sediment characteristics as well as man-made constructions are often difficult to incorporate into process studies like e.g. numerical analysis. Comparison with other catchments or extraordinary hydrological events is difficult due to a lack of adequate data (Church, 2002). The need for comparative data, however, is highlighted due to two major issues. At first the high pressure on the floodplains, especially in densely populated areas, has to be mentioned. Edegger (2008) pointed out, that an increase of settlement areas in Austria until 2031 up to 17\% $\left(3.335 \mathrm{~km}^{2}+565 \mathrm{~km}^{2}\right)$ mainly close to urban centres can be expected. This is particularly difficult due to the fact that in Austria only $32 \%$ of the land can be used for permanent settlement, whereas so far $13.5 \%$ is already used (ÖROK, 2005).

The second one is that in Europe hazard zone plans are used as a traditional instrument in spatial planning but exhibited a range of various risk zones, due to national specifications. In the present situation the approved European Floods Directive (Directive 2007/60/EC on the assessment and management of flood risks), however, provides guidelines for standardized flood risk analysis to the member states. Nevertheless, the implementation of the new directive faces some major concerns in the future. In hazard zone

Published by Copernicus Publications on behalf of the European Geosciences Union. 
plans so far no risk zones due to morphodynamic changes are included. One reason is that no universal prediction tool is available for quantification of width changes. However, considering a certain defined river corridor (due to lateral erosion, overbank deposition, overbank scouring, avulsions) to reduce damage potential during flood hazards have to be seen as an established approach in some European Countries (Piégay et al., 2005; FOWG et al., 2000). The determination of the morphodynamic active river corridor uses a variety of methodologies. One approach is based on analysing (numerically) flood hydraulics that may be affected due to lateral or longitudinal disturbances (geomorphologic/anthropogenic) of the channel- and floodplain geometry on especially the local scale. Those local disturbances are crucial for the onsite- (e.g. scouring) but as well for the downstream morphodynamics (e.g. constriction-expansion processes) during floodings. Previous studies, however, have shown that it is difficult to describe morphological processes during extraordinary discharges on a local scale based on single hydraulic parameters (Miller, 1990), despite efforts in this direction (Kale, 2007; Cenderelli and Wohl, 2003a; Barker et al., 2009; Ortega and Heydt, 2009). Hauer and Habersack (2009) investigated different hydraulic and geomorphic parameters and concluded that lateral constrictions and expansions of the valley geometry led to scouring and aggradation within the inundated areas during the flood hazard. However, beside the variety of single event studies there is a lack of comparative data and analyzed processes dealing with the impact of one meteorological extreme event (e.g. heavy precipitation) on the morphodynamics of different rivers. Many articles addressing catastrophic floods (extraordinary precipitation/dam breaking) were conducted within one river basin (Phillips, 2002; Cenderelli and Wohl, 2003b; Brooks and Lawrence, 1999) without the possibility to extrapolate or analyze the impact on neighboring river catchments. Thus, the impacts on morphodynamics and the derived cause-effect studies have to be seen as a site and/or river specific result not allowing a generalization of cause-effect processes which might be used for improving and extending hazard zone plans and thus preventing high socioeconomic losses. Within most of the presented studies the specific stream power was used to assess the geomorphic impact of floods by defining thresholds for major morphological adjustments. The stream power as a parameter to quantify the energy exerted on the river bed and banks was widely approved and applied for cause-effect analysis related to various river types (Miller, 1990; Magilligan, 1992a; Benito, 1997; Eaton et al., 2004).

It is hypothesized in the presented paper that at larger scales the specific stream power is able to predict river width changes during flood hazards. In large scale investigations (reach/sub-reach scale), where parameter means are considered, the specific stream power should correlate with e.g. the average width changes caused by the extreme floodings. Especially at the reach scale a

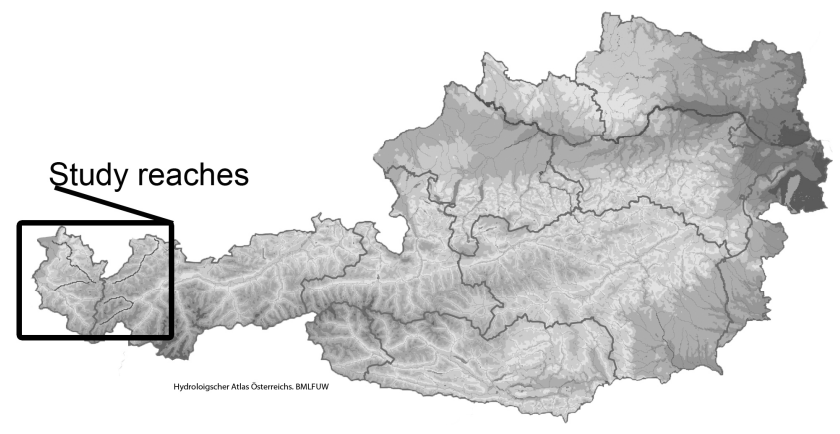

Fig. 1. Investigated study reaches in the Alpine regions of Austria (map: Hydrological Atlas of Austria, BMLFUW).

screening tool based on stream power should allow the definition of the so called "minimum morphological spatial demand" (morphodynamic active area during floodings with a recurrence interval $>100$ ) which should improve flood risk assessment and flood risk management. Moreover it is hypothesized, that on the local scale reach averaged hydraulic parameters (e.g. stream power) are not able to predict site specific width changes and that additional parameters are necessary to determine local scouring or aggradation. Thus, the present paper (i) assess the effects of the extreme floods in 2005 based on width changes in 5 alpine catchments in Austria and (ii) based on the comparative cause-effect analysis a screening tool for the sub reach and reach scale should be derived.

\section{Study reaches}

The catastrophic floods 2005 in the western (alpine) part of Austria (Fig. 1) were caused by so called $V b$ meteorological conditions (Habersack et al., 2009). These are similar to those that severely impacted (recurrence interval partially $>1000$ years) the northern and eastern part of Austria in August 2002 (Habersack and Moser, 2003; Lebensministerium, 2006). Characteristic for those weather conditions is a displaced low-pressure area in northern Italy, which caused heavy precipitation over the Alpine regions in August 2005. In some areas the highest recorded discharges ever were documented. At the gauging station Landeck (Sanna River - confluence of Trisanna and Rosanna), for example, a peak discharge of $514 \mathrm{~m}^{3} \mathrm{~s}^{-1}$ (recurrence interval $\sim 5000$ years) was recorded on 28 August. Four people died in the course of the floods. Financial losses amounted to around 600 million $€$.

The catastrophic floods in Tyrol and Vorarlberg impacted especially five gravel bed rivers with floodplains mainly formed by Alluvium. Their valleys were shaped through glacial erosion which led to deepening and widening. The Lech and Bregenzerach Rivers were historically classified partially as high dynamic braided rivers. Alfenz, Rosanna 
Table 1. Hydrologic and hydraulic characteristics of the analysed rivers.

\begin{tabular}{lcccccccc}
\hline & $\begin{array}{c}\text { Drainage } \\
\text { area }\end{array}$ & $\begin{array}{c}\text { Mean annual } \\
\text { areal } \\
\text { precipitation }\end{array}$ & $\begin{array}{c}\text { Study } \\
\text { reach } \\
\text { length }\end{array}$ & $\begin{array}{c}\text { Mean } \\
\text { bed } \\
\text { slope }\end{array}$ & $\begin{array}{c}\text { Maximum } \\
\text { discharge } \\
\text { August 2005 }\end{array}$ & $\begin{array}{c}\text { Mean } \\
\text { annual } \\
\text { discharge }\end{array}$ & $\begin{array}{c}\text { Recurrence } \\
\text { intervall } \\
100 \text { years }\end{array}$ & $\begin{array}{c}\text { Mean } \\
\text { annual } \\
\text { flood }\end{array}$ \\
\hline Trisanna & 409 & 1.547 & 34 & 0.0230 & 282 & 9 & 156 & 74 \\
Lech & 1.211 & 1.769 & 51 & 0.0063 & 938 & 44 & 657 & 368 \\
Bregenzerach & 843 & 2.230 & 56 & 0.0088 & 1.334 & 46 & 1.200 & 606 \\
Rosanna & 248 & 1.696 & 20 & 0.0213 & 184 & 9 & 125 & 59 \\
Alfenz & 172 & 1.673 & 22 & 0.0246 & 77 & 4 & 63 & 30 \\
\hline
\end{tabular}

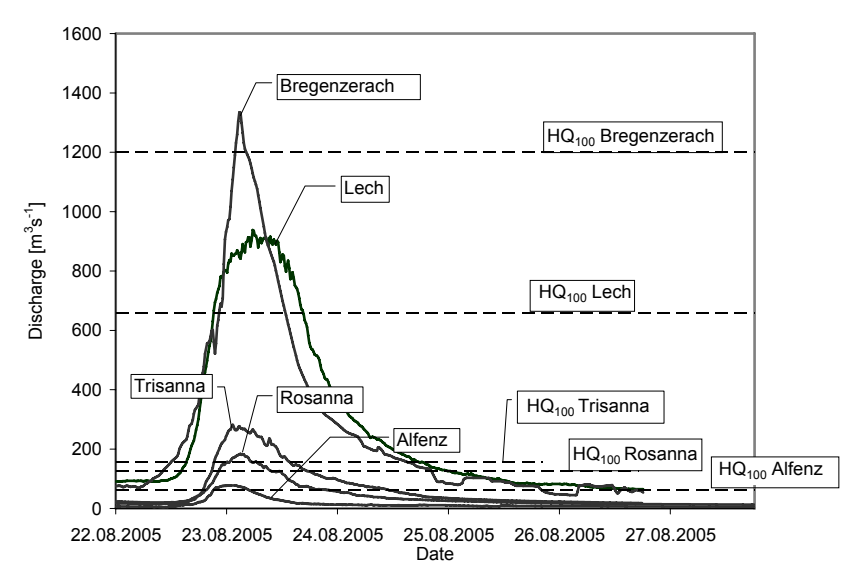

Fig. 2. Hydrographs of the August 2005 flood at the Bregenzerach, Lech, Trisanna, Rosanna and Alfenz Rivers; horizontal lines marking 100 years flood values $\left(\mathrm{HQ}_{100}\right)$ (Hydrographic Service, 2005).

and Trisanna Rivers historically exhibited straight and pendular river morphology with locally braided sub reaches (Muhar et al., 2004). The Lech and the Bregenzerach Rivers have the largest catchment areas $\left(1211 \mathrm{~km}^{2} / 843 \mathrm{~km}^{2}\right)$ and thus the highest mean annual flood discharges $\left(368 \mathrm{~m}^{3} \mathrm{~s}^{-1} / 606 \mathrm{~m}^{3} \mathrm{~s}^{-1}\right)$ (Table 1$)$. The mean annual flood discharges of the Trisanna and Alfenz Rivers are lower $\left(74 \mathrm{~m}^{3} \mathrm{~s}^{-1} / 30 \mathrm{~m}^{3} \mathrm{~s}^{-1}\right)$ but they exhibit the highest average bed slopes $\left(0.0230 \mathrm{~m}^{1} \mathrm{~m}^{-1} / 0.0246 \mathrm{~m}^{1} \mathrm{~m}^{-1}\right)$. The average river width before the flood in 2005 varied between $12 \mathrm{~m}$ and $49 \mathrm{~m}$ for the Alfenz, Rosanna, Trisanna and Bregenzerach Rivers and was around $80 \mathrm{~m}$ for the Lech River. Mean annual precipitation varies between $1673 \mathrm{~mm}$ (catchment of the Aflenz River) and $2230 \mathrm{~mm}$ (catchment of the Bregenzerach). Table 1 summarizes the hydraulic and hydrologic characteristics of these five rivers.

Figure 2 shows the hydrographs during the August 2005 flood for the analysed rivers.

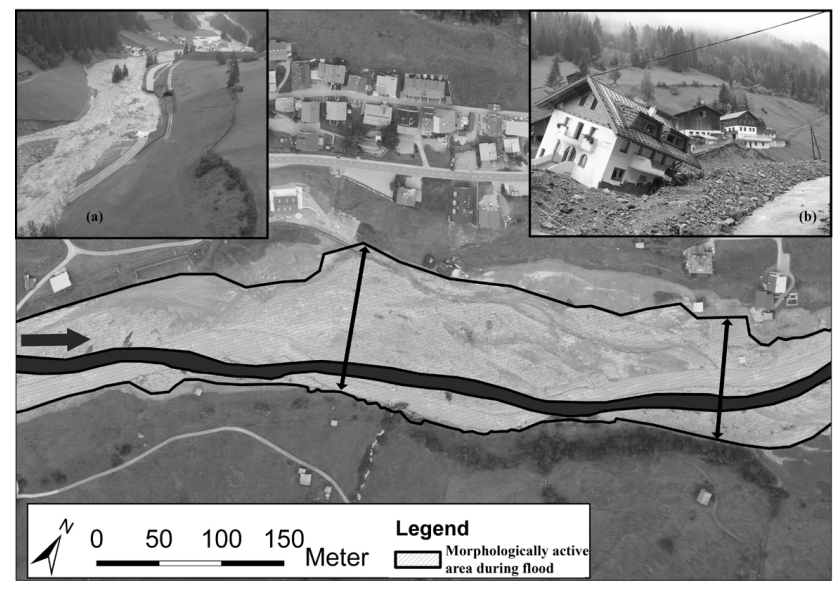

Fig. 3. Morphologically active area at the Trisanna River during the extreme flood 2005, the insert photos show the flood hazard on 23 August 2005 with the (a) whole valley bottom inundated and (b) a house affected by erosion after the flood (photo: State of Tyrol, BBA Imst, BOKU-IWHW).

Figure 3 shows the Trisanna River before the flood as well as the morphologically active area during the extreme flood in 2005. The river in this sub reach before the flood was exhibiting a straight stretch with a river width of approx. $10 \mathrm{~m}$. The arrows show the measured river width after the flood (up to $120 \mathrm{~m}$ ) for calculation of the river width ratio. Especially in alpine valleys little space for settlements and industrial development is available. Hence in the last decades developments close to rivers were conducted and led to an increase of the vulnerability there. Buildings closer to Trisanna were severely affected due to erosion as apparent on the insert photo of Fig. 3.

\section{Methodology}

Multiple datasets were used to analyse the morphological changes (e.g. lateral erosion, overbank deposition, overbank scouring, avulsions) during the 2005 floods. Morphological 

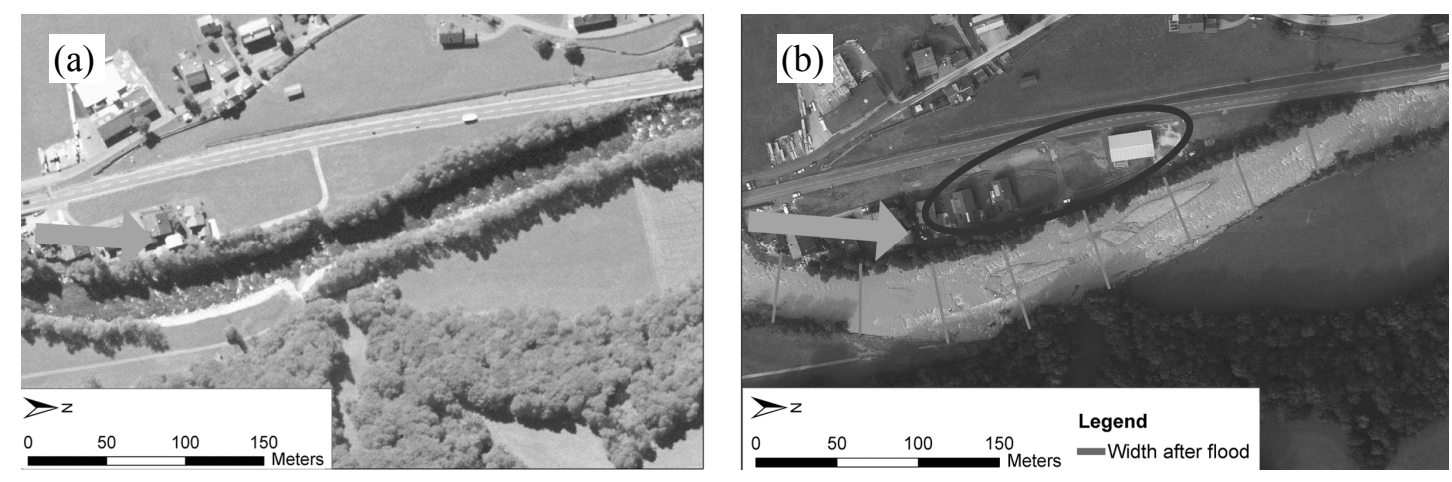

Fig. 4. Bregenzerach (a) before (November 2002) and (b) after the flood (September 2005), (b) grey lines showing the measured river width after the flood; the ellipse in (b) marks the new buildings in the vicinity of the Bregenzerach River (photo: State of Vorarlberg).

changes are considered relevant if lateral erosion of banks or aggradation on the floodplain exceed 2-m distance from the pre-flood embankment. Figure 4 shows the Bregenzerach River before and after the flood. The measured width after the flood is indicated with grey lines in the right picture of Fig. 3 and describes the morphologically active area where material is eroded (floodplain scouring) during the 2005 flood. Moreover, in Fig. 4b also the increase of the vulnerability in the vicinity of rivers can be seen due to construction of new buildings.

Orthoimages provided by the States Tyrol and Vorarlberg, before (November 2002) as well as orthoimages produced immediately after the catastrophic event (September 2005), were fundamental for analysing the morphological changes after the floods 2005. Similar methods were applied by Mount et al. (2003) and Reinfelds (1997). The width changes of the five rivers (Trisanna, Rosanna, Lech, Bregenzerach, Alfenz) were measured in GIS (based on the orthoimages) and the width ratio $R_{\mathrm{w}}$ (i.e. width after/before the flood) was calculated. The width ratio is used as a parameter to describe the morphodynamic activity in terms of e.g. lateral erosion, avulsions and overbank scouring.

$R_{\mathrm{w}}=\frac{w_{\mathrm{after}}}{w_{\text {before }}}$

where $w_{\text {after }}[\mathrm{m}]$ is width where material was eroded or aggraded during the flood, $w_{\text {before }}[\mathrm{m}]$ is width before the flood, $R_{\mathrm{w}}[-]$ width ratio.

GIS was further used to investigate the flood-related morphological changes based on a scaling approach (Habersack, 2000). Three scales of analysis were differentiated: reach scale (range: $20-56 \mathrm{~km}$ ); sub reach scale $(500-5000 \mathrm{~m})$; local scale (single profiles).

On the reach scale (range: $20-56 \mathrm{~km}$ ) the mean specific stream power was calculated for the entire river and correlated with the average width ratio for the Rosanna, Trisanna, Lech, Bregenzerach and Alfenz Rivers.
For the sub reach scale analysis homogenous river reaches ( $n=15$, Aflenz River; $n=14$, Rosanna River; $n=7$, Trisanna River, $n=9$, Bregenzerach River; $n=13$, Lech River) were determined where the alteration of $R_{\mathrm{w}}$ values of adjacent cross sections were maximum $30 \%$. The width ratios in sub reaches from $500 \mathrm{~m}$ to $5000 \mathrm{~m}$ were averaged and correlated with the average specific stream power $\left[\mathrm{Wm}^{-2}\right]$.

On the local scale, before and after the flood widths were measured for a cross sectional spacing of $200 \mathrm{~m}(n=107$, Aflenz River; $n=98$, Rosanna River; $n=137$, Trisanna River; $n=181$, Bregenzerach River; $n=208$, Lech River). The width ratios were categorized in 9 classes to obtain a satisfactory distribution of cross sections in each class for more detailed analysis. Each width ratio class describes a $\Delta R_{\mathrm{w}}$ of 0.2. Class 1 includes cross sections where the river width before and after the flood did not change, whereas class 9 describes width ratios larger than 2.4. The flow area was standardized by dividing each cross section value (e.g. river width) by the mean value of the entire reach. For the cause-effect analysis the flow area (cause) was plotted against width ratio classes (effect).

Based on 1-D hydrodynamic-numerical modelling (HECRAS) with geometry data before the flood (State of Vorarlberg, 2007; State of Tyrol, 2007), the parameters specific stream power $\left[\mathrm{Wm}^{-2}\right]$, shear stress $\left[\mathrm{Nm}^{-2}\right]$ and the cross sectional flow area $\left[\mathrm{m}^{2}\right]$ of the channel were calculated for the 2005 event $\left(430 \mathrm{~m}^{3} \mathrm{~s}^{-1}\right.$ Bregenzerach $/ 361 \mathrm{~m}^{3} \mathrm{~s}^{-1}$ Lech River). The calculation of the specific stream power for the Alfenz, Rosanna and Trisanna Rivers was based on cross sections extracted from airborne LiDAR digital terrain models (before the flood) neglecting cross sectional shape below water surface. The resolution of the LiDAR data points is $1 \times 1 \mathrm{~m}$ with an adequate altitude accuracy (Höfle et al., 2009). Figure 5 shows the used LiDAR data at the Bregenzerach River. 


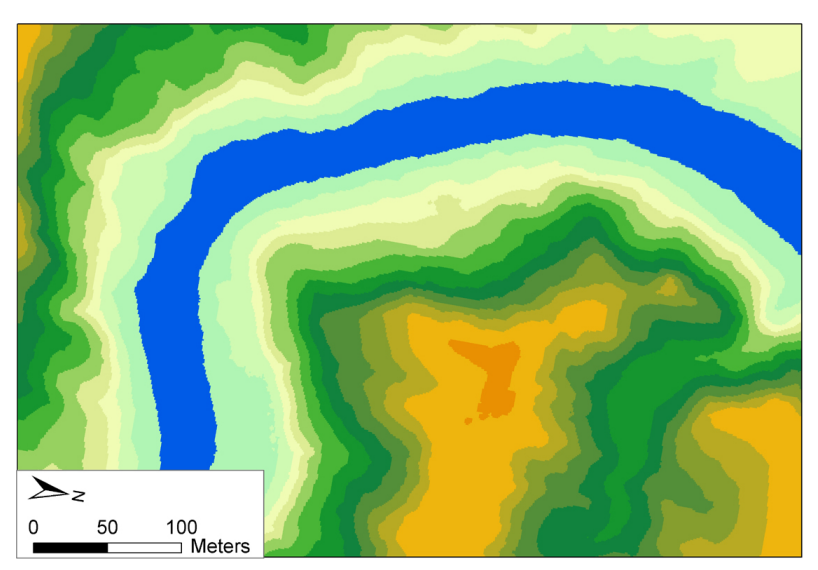

Fig. 5. LiDAR data of the Bregenzerach River; resolution of the data points is $1 \times 1 \mathrm{~m}$.

According to the cross section based hydraulic parameter analysis Knighton (1999) defines the total stream power per unit channel length $\Omega\left[\mathrm{Wm}^{-1}\right]$ by:

$\Omega=\gamma Q S$

where $\gamma$ is the specific weight of water $\left(9810 \mathrm{~N} \mathrm{~m}^{-3}\right), Q$ is peak discharge in $2005\left[\mathrm{~m}^{3} \mathrm{~s}^{-1}\right]$, and $S$ is energy slope $\left[\mathrm{m} \mathrm{m}^{-1}\right]$, which may be approximated by the water slope from LIDAR data.

The total power supply per unit bed area is described in Bagnold (1977). The corresponding specific stream power $\left[\mathrm{Wm}^{-2}\right]$ is given by:

$\omega=\frac{\Omega}{w}=\frac{\rho g Q S}{w}$

where $w$ is the channel width before the flood [m].

Equation (3) defines the rate at which potential energy is provided to a unit area of the river bed. Thus, stream power and potential energy are fundamentally linked (Kale, 2007).

The bottom shear stress is calculated with:

$\tau=\gamma R S$

where $R$ is the hydraulic radius [m].

To allow comparative cause-effect analysis between the different rivers the specific discharge at the mean annual flood (cause) was calculated and illustrated with the width ratios (effect) of the Trisanna, Rosanna, Lech, Bregenzerach and Alfenz Rivers. Further the ratio of the mean annual discharge to the peak discharge of the flood $2005\left(Q_{\max }\right)$ was calculated standardized by the mean annual flood $\left(Q_{1}\right)$ for the Bregenzerach and Lech Rivers and plotted against the standardized shear stress (based on 1-D hydrodynamicnumerical modelling). Moreover, the shear stress and specific stream power were illustrated with the drainage area for the Bregenzerach and Alfenz Rivers. There, a comparison with the work of Magilligan (1992a) was possible, where a threshold for specific stream power $\left(300 \mathrm{Wm}^{-2}\right)$ and shear stress $\left(100 \mathrm{Nm}^{-2}\right)$ for major morphological adjustments during floods were defined.

\section{Results}

At first a general overview of the flood impacts is presented. The morphodynamic activity of the Rosanna, Trisanna, Lech, Alfenz and Bregenzerach Rivers during the extreme floods in August 2005 is illustrated in Fig. 6. To gain an overview of the initial river width (pre-flood morphodynamically active channel), the distribution of river width before the flood is indicated on the x-axis. The plots of the Trisanna and the Rosanna Rivers show that the river width before the flood was $<20 \mathrm{~m}$ in nearly $100 \%$ of the cross sections at the Trisanna and more than $80 \%$ of the cross sections at the Rosanna River. The highest width ratios were found at these rivers. The greater initial river width at the Lech (lower reach $\sim 80 \mathrm{~m})$ and the Bregenzerach $(\sim 50 \mathrm{~m})$ Rivers resulted in smaller width ratios after the extreme floods (Fig. 6). The investigated rivers were subject of regulation decades ago which induced narrowing of the rivers. However, based on these findings, neither, a comparative analysis, nor relevant cause-effect analysis could be derived.

Thus, within a second step, the specific discharge at the mean annual flood was used to explain, in a comparative view, the occurred width changes during the extreme floods. In Fig. 7 the specific discharge at the mean annual flood is plotted against the width ratio to compare the 5 investigated rivers. At cross sections with smaller specific discharge $\left(<5 \mathrm{~m}^{2} \mathrm{~s}^{-1}\right)$ higher width ratios occurred during the extreme floods. Only at the Trisanna River single outliers at a specific discharge higher $10 \mathrm{~m}^{2} \mathrm{~s}^{-1}$ led to larger width ratios and can be found due to small river widths there. Interesting findings that indicate that there are two distinctive types of rivers impacted by the floods. One group is found for heaving lower pre-flood widths (e.g. Bregenzerach River) with higher width-ratios compared to the second one with initially wider stream bed (e.g. Lech River) featuring lower width-ratios after the flood impacts in 2005.

Therefore, within a third analysis, before addressing the processes at various scales, a comparison of two groups of rivers is presented. With increasing discharge (from the mean annual discharge to the peak discharge of the floods in 2005) the shear stress distribution was used to illustrate the increasing energy exerted on the channel leading to width changes (Fig. 8). An obvious difference of the discharge related graphics of shear stress exists between the mean annual discharge and $Q_{30}$ at the Bregenzerach River (small pre-flood width) compared to the range between $Q_{30}$ and $Q_{300}$. Especially the high energy up to the 30 years recurrence interval within the active channel led to overbank scouring (observed based on the analysis of the orthoimages) in the floodplains of the Bregenzerach River when run-off exceeded the hundred-years event overtopping longitudinal dams. In contrast, for the Lech River (large pre-flood width) a near linear increase of the shear stress from the mean annual discharge to the $Q_{300}$, was calculated, due to the larger flow areas in the active channel as well as in the flood 

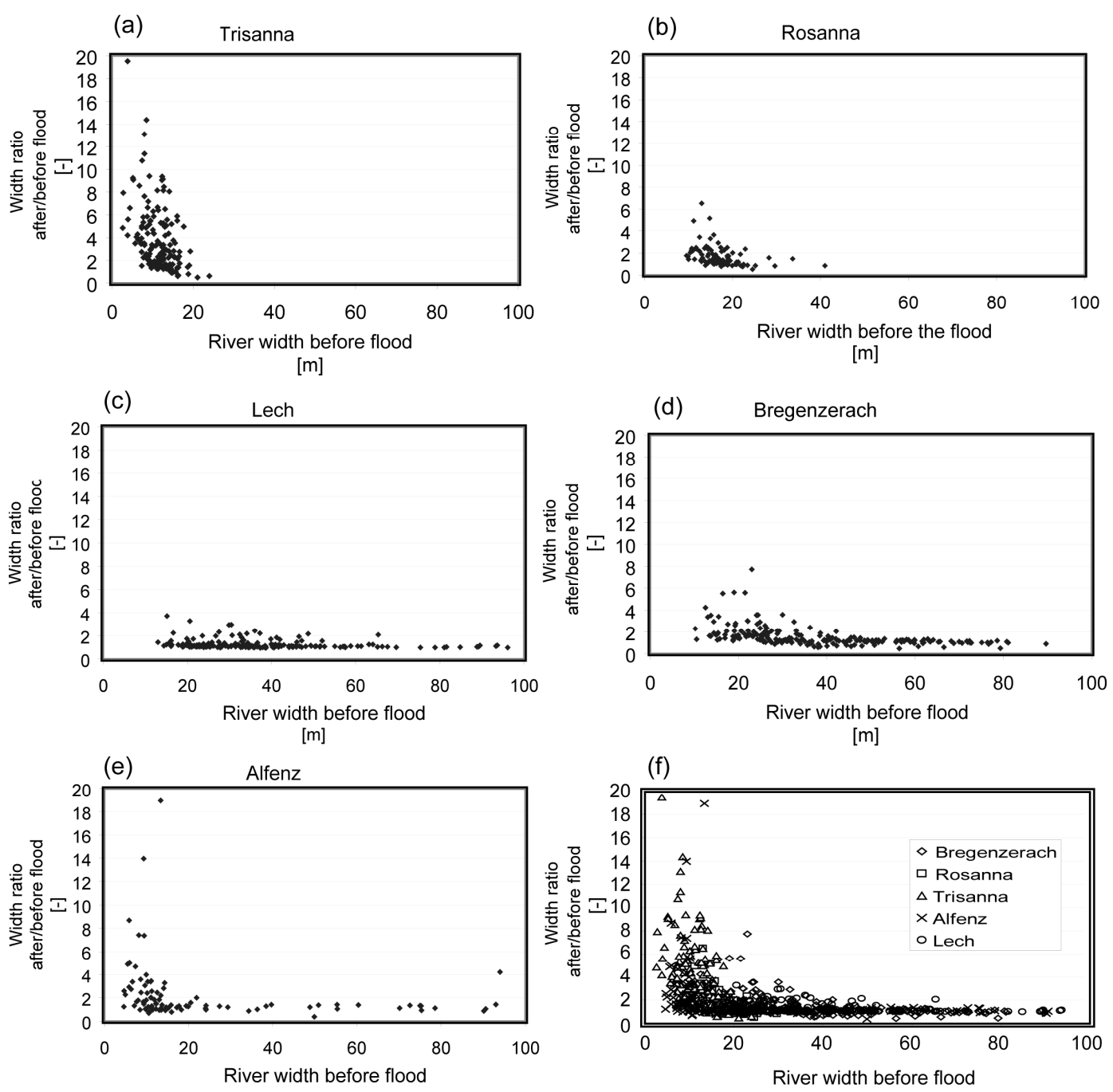

[m]

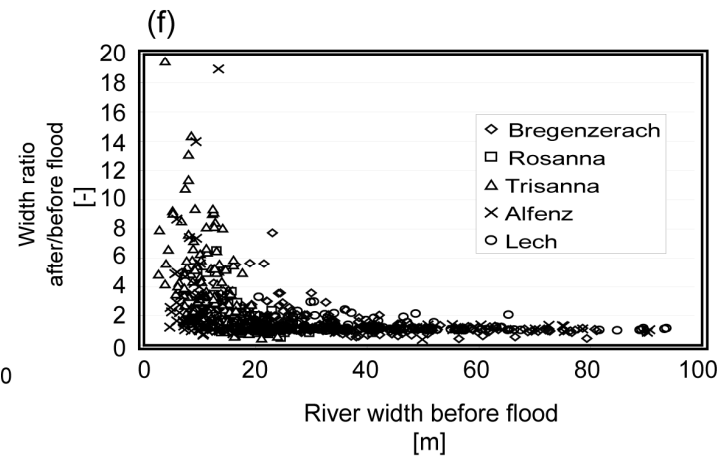

Fig. 6. River width before the flood and the width ratio after the flood at Trisanna (a), Rosanna (b), Lech (c), Bregenzerach (d) and Alfenz (e) Rivers; the river width before the flood and the width ratios after the flood of the 5 rivers are shown in (f).

plain areas leading to a minor increase in flood stage and flood power. Thus the findings of Fig. 6 might be an indicator for the differences in width ratios between the group of small to large pre-flood rivers which are presented in Fig. 5.

\subsection{Reach scale analysis}

As one of the aims of the presented paper the process analysis of flood morphodynamics was addressed on various scales. Focusing on the reach scale mean values of the specific stream power and the width ratios were correlated to analyse the river widening during the extreme floods (Fig. 9). Based on the significant correlation $\left(R^{2}=0.96\right)$ for the 5 different rivers the hypothesis was verified that specific stream power can be used as a screening tool to assess morphological changes after extreme floods in gravel bed rivers. Using mean values for the river reach implies all single values and at the same time allows an analysis for the whole river reach.

\subsection{Sub reach scale analysis}

In a downscaling approach the mean specific stream power values and the width ratio were calculated for homogeneous river sections. The largest river morphological impacts, with width ratios up to 6.4 and specific stream power values up to $6780 \mathrm{Wm}^{-2}$, were calculated at the Trisanna River. Specific stream power values $<2000 \mathrm{Wm}^{-2}$ were determined at the Lech and for most sub reaches of the Bregenzerach River. The mean width ratios for both rivers were $<2$. The Alfenz River showed a wide spectrum of specific stream power values $\left(460-5650 \mathrm{Wm}^{-2}\right)$. Based on the findings of Fig. 10 a new equation (Eq. 5) could be derived, which might be used as a screening tool in flood hazard analysis. In total 


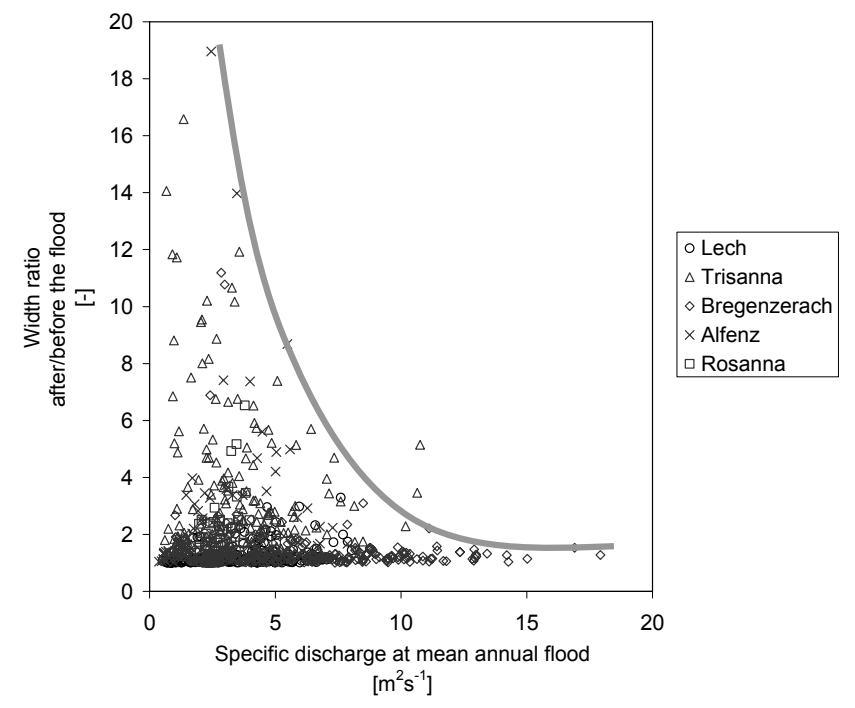

Fig. 7. Specific discharge at mean annual flood and the width ratios at the Trisanna, Rosanna, Lech, Bregenzerach and Alfenz Rivers; the envelope curve marks the maximum values; single outliers at the Trisanna River can be seen due to small river width at this cross sections.

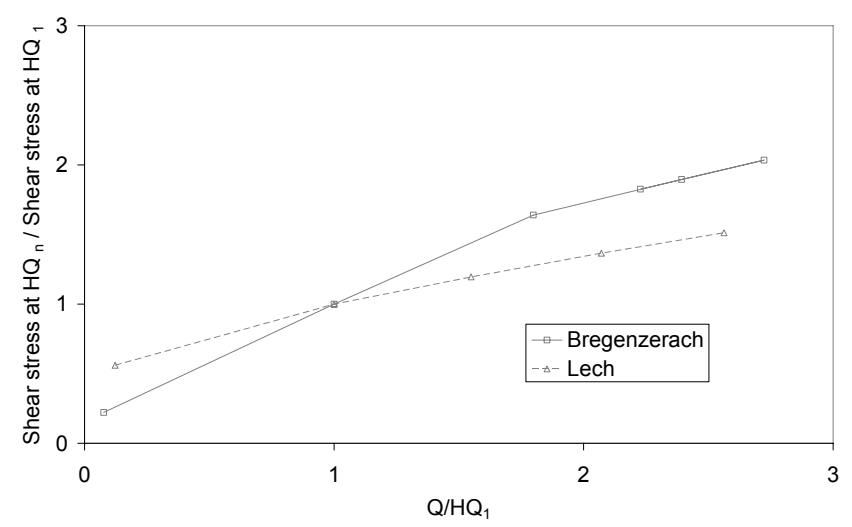

Fig. 8. Shear stress ratio with increasing discharge. Both shear stress ratio and discharge ratio are expressed as the ratio of the mean annual discharge to a given design flood $\left(Q_{1}-Q_{300}\right)$ respectively flood 2005 peak discharge to their annual flood discharge to permit standardization.

58 sub-reaches from 5 different gravel bed reaches were investigated leading to a linear relationship between mean specific stream power and width ratio after/before the floods in 2005 .

$y=0.0007 x+0.8182$

where: $y=$ width ratio after/before the flood $[-] ; x=$ mean specific stream power $\left[\mathrm{Wm}^{-2}\right]$.

Figure 10 illustrates the relation of the specific stream power and width ratios for each sub reach of the Trisanna, Rosanna, Lech, Bregenzerach and Alfenz Rivers and resulted in a significant correlation $\left(R^{2}=0.72\right)$. On the sub reach

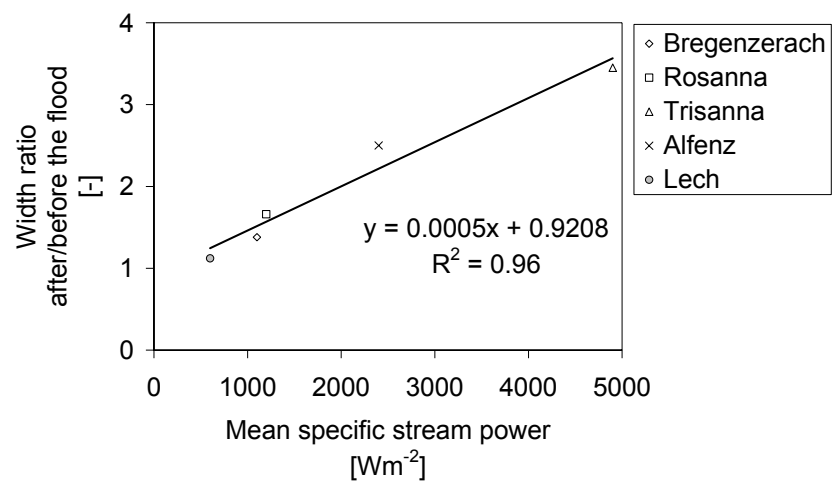

Fig. 9. Mean river width ratios and mean specific stream power at the Lech, Bregenzerach, Rosanna, Alfenz and Trisanna Rivers before the extreme flood 2005 on the reach scale analysis.

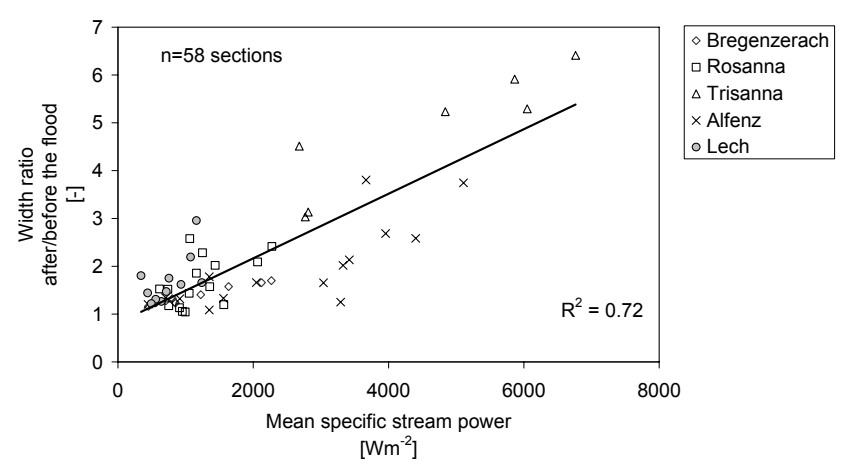

Fig. 10. Width ratios and mean specific stream power values in 58 sections at the Trisanna, Rosanna, Lech, Bregenzerach and Alfenz Rivers on the sub reach scale.

scale standard deviation (1.346) is increasing compared to the standard deviation on the reach scale (0.952). Maximum values of the width ratio are increasing compared to the reach scale e.g. at the Trisanna River from 3.45 to 6.41 and the Rosanna from 1.66 to 2.58 .

In all evaluated sub reaches lateral erosion and hence widening of the rivers occurred. The drainage area can be used to show the distribution of the specific stream power and the shear stress at the Bregenzerach and Lech Rivers (Fig. 11). The largest width ratios $R_{\mathrm{W}}(1.66 / 2.96)$ exhibit the largest energy values on the river bed. No downstream increase of width changes can be observed. Values for the specific stream power at the Lech and Bregenzerach Rivers range from $341 \mathrm{Wm}^{-2}$ to $2384 \mathrm{Wm}^{-2}$. The thresholds of $300 \mathrm{Wm}^{-2}$ for the specific stream power and $100 \mathrm{Nm}^{-2}$ for shear stress for major morphological adjustments during floods proposed by Magilligan (1992a) were supported at the investigated sub reaches at the Bregenzerach River. In contrast to the Bregenzerach River also shear stress values below the proposed threshold of $100 \mathrm{Nm}^{-2}$ at the Lech River can be found. 

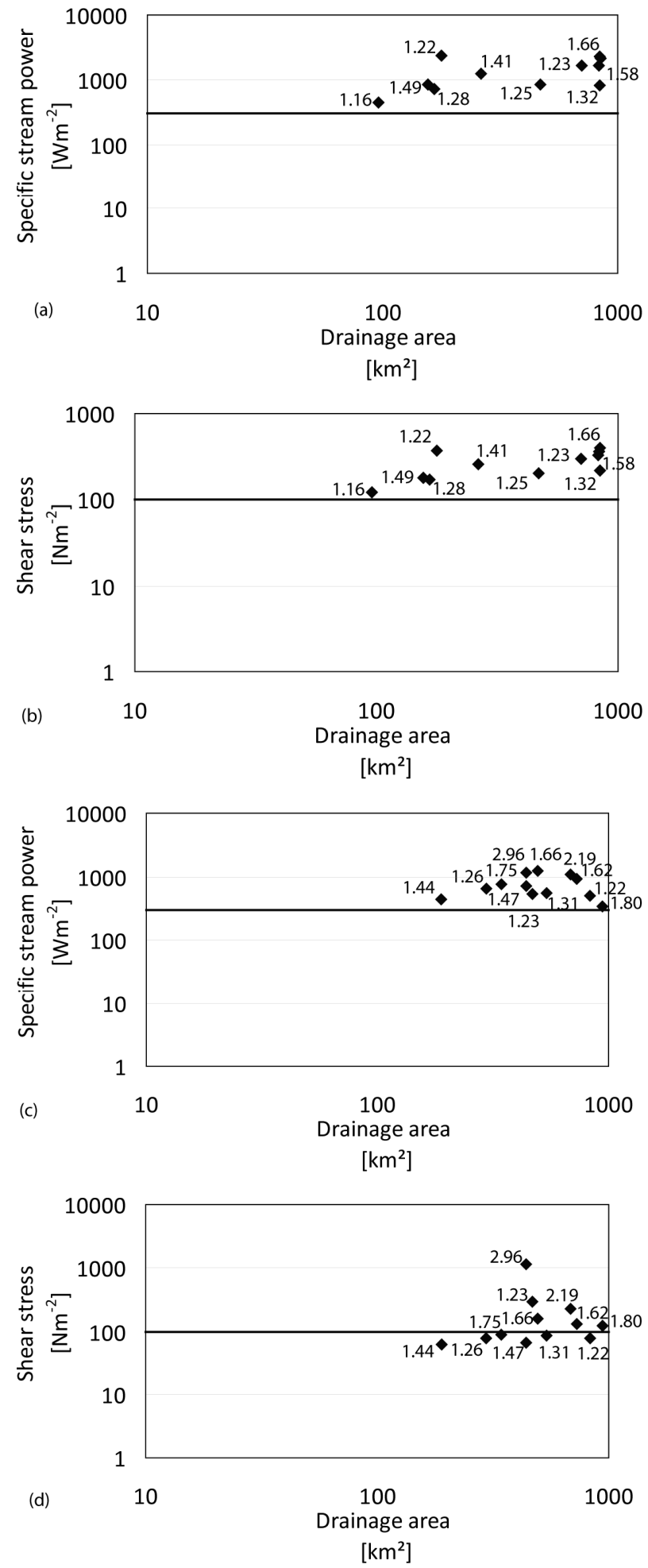

Fig. 11. Specific stream power and shear stress versus drainage area at the Bregenzerach $(\mathbf{a}, \mathbf{b})$ and Lech Rivers $(\mathbf{c}, \mathbf{d})$ on the sub reach scale; width ratio values $\left(R_{\mathrm{W}}\right)$ are illustrated, proposed specific stream power $\left(300 \mathrm{Wm}^{-2}\right)$ and shear stress $\left(100 \mathrm{Nm}^{-2}\right)$ thresholds by Magilligan (1992a) are shown with horizontal lines.

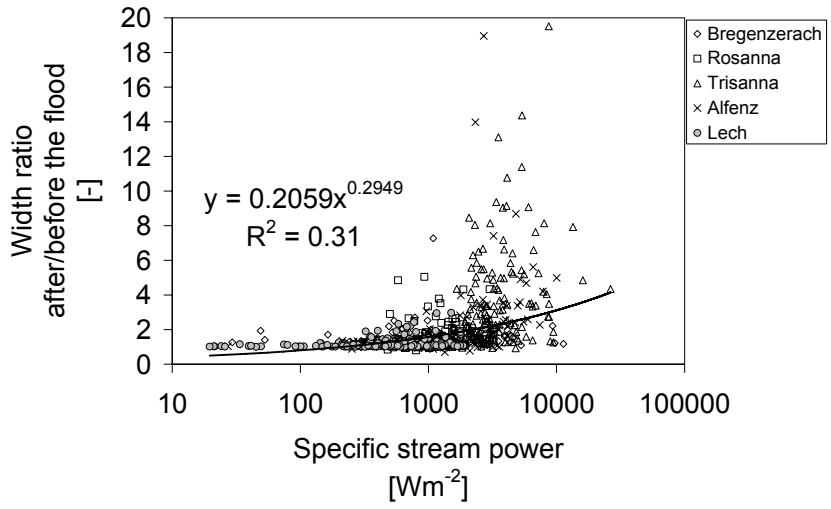

Fig. 12. Width ratio $\left(R_{\mathrm{W}}\right)$ and specific stream power values for the flood 2005 based on cross sections at the local scale.

\subsection{Local scale analysis}

On the local scale single cross section values for the specific stream power scatter with the width ratio (Fig. 12). On this scale it was found, that it is not possible anymore to correlate one single hydraulic parameter with the width changes based on the applied methods. Hence more detailed hydraulic as well as qualitative analysis would be necessary to quantify the minimum morphological spatial demand on the local scale.

Major morphological adjustments $\left(R_{\mathrm{W}}>2\right)$ after the extreme flood occur at single cross sections larger than $300 \mathrm{Wm}^{-2}$ e.g. at the Rosanna River with a specific stream power of $500 \mathrm{Wm}^{-2}$. Only at the Trisanna River large width changes at 2 cross sections occurred $\left(R_{\mathrm{w}}=1.93\right.$, respectively 1.70) having a specific stream power smaller than the proposed threshold of $300 \mathrm{Wm}^{-2}$. Single $R_{\mathrm{W}}$ values were found at the Trisanna and Alfenz Rivers of nearly 20 . The standard deviation of all with ratios is 2.17 , which is the largest compared to the local and sub reach scale.

Classes of width ratio were once more used for the Lech and the Bregenzerach River (representing the two groups of rivers with small- and large pre-flood width) to illustrate the morphological changes during the 2005 flood versus the relative values of the flow area (Fig. 13). At river cross sections with smaller relative flow areas $(<1)$, the stress on the river banks is higher, leading to large width ratios during the flood. At width ratio classes 1, 2 and 3 a large standard deviation at the Bregenzerach and Lech River can be found (0.86), confirming furthermore the difficulty to asses the minimum morphological spatial demand of rivers out of single hydraulic parameters on the local scale. 

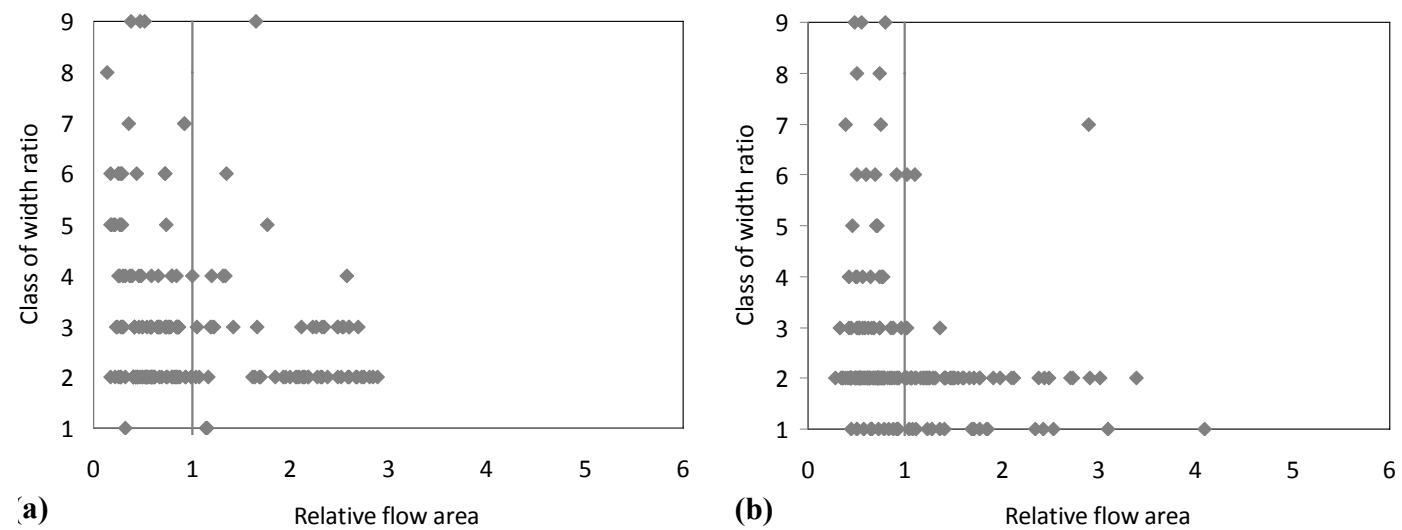

Fig. 13. Width ratios classes versus relative flow area at the (a) Bregenzerach and (b) Lech Rivers based on single cross section values; $76 \%$ respectively $88 \%$ of the relative flow area at the Bregenzerach and Lech Rivers is in the classes 1, 2 and 3.

\section{Discussion}

Scaling river processes were successfully applied in various research projects and enabled satisfactory results (Astrade and Bravard, 1999; Habersack, 2000). Moreover the findings of the presented study highlight, based on different scales, that a good assessment of morphological adjustments during extreme flood hazards is feasible. This study uses three scales (reach, sub reach, local) to point out the possibilities and limitations when correlating width changes with hydraulic parameters. For the assessment of the effectiveness of large-magnitude and infrequent floods basin factors (e.g. basin morphometry, rock and soil type, vegetation) and channel factors (e.g. gradient, channel and floodplain morphology, flow boundary material, sediment availability) that influence channel and valley responses to extreme floods have to be considered (Kochel, 1988). Based on hydraulic parameters extreme floods can be quantified and correlated with the geomorphic effects (Magilligan, 1992a; Miller, 1990; Cenderelli and Wohl, 2001). The geomorphic effectiveness is defined as the modification of landforms (Wolman and Gerson, 1978) and is quantified in this paper based on river width measurements before and after the floods of 2005.

To date many studies focused on finding thresholds of hydraulic parameters (specific stream power, shear stress) when rivers are eroding, stable or aggrading (Breitenbaumer, 2008; Miller, 1990; Stacey and Rutherfurd, 2007; Bledsoe and Watson, 2001; Magilligan, 1992a; Benito, 1997) based on modeling and/or field observations. Magilligan (1992b) suggested a threshold of $300 \mathrm{Wm}^{-2}$ for major morphological adjustments. Mean specific stream power values in this study exhibited a large variability with river erosion from $341 \mathrm{Wm}^{-2}$ to $4900 \mathrm{Wm}^{-2}$ and hence support the results of Magilligan (1992a). Limitations regarding the threshold for shear stress have to be pointed out, due to width changes in sub reaches with shear stress values below $100 \mathrm{Nm}^{-2}$ at the Lech River.
This study adds to the knowledge and quantifies the morphological adjustments using the width ratio $\left(R_{\mathrm{W}}\right)$ and finds a significant correlation of the width ratio with the specific stream power on the reach and sub reach scale. Averaging the specific stream power and width ratio on the reach scale incorporates local disturbances and extreme values. Larger variance of the hydraulic parameters can be found on the sub reach scale, leading to a weaker correlation. Local scale analysis includes information of lateral and longitudinal disturbances (Eaton and Lapointe, 2001) and at the same time leads to larger scatter of the data. Constraints like massive construction works (e.g. bridges, tunnels, concrete walls) can distort the results compared to natural conditions (Church, 2002). At the Austrian Kamp River (mixed alluvial river), flow constriction and expansion were responsible for an increase in local erosional power, leading to partially extensive overbank scouring in the floodplains downstream of constricted river reaches (e.g. bridges) (Hauer and Habersack, 2009). Overbank scouring can also be acknowledged to a nonlinear increase of shear stress (e.g. Bregenzerach River), when the mean annual flood is exceeded, where this study supports findings of Magilligan (1992a). Clearly, a range of further parameters influence the geomorphic role of floods. These include the flood-generating mechanism, position within a drainage basin, erosional threshold, sediment supply, sediment size, land use, in-channel wood, riparian vegetation and time since the last flood (Wohl, 2007; Papa et al., 2004). During extreme floods rivers are widening and using space for morphological adjustments depending on preceding parameters. In Austria this leads to particularly problems due to the limited space for buildings and infrastructure available and further to an increasing risk of erosion in the vicinity of rivers (Habersack et al., 2009). It is therefore even more important to keep a minimal distance (minimum morphological spatial demand) from rivers without buildings and infrastructure to reduce risk of erosion there. 
Miller (1990) concluded, that more detailed investigations are required to determine the local interaction between flood flow patterns and morphological changes (aggradation/erosion) over the valley floor. Especially on the local scale specific stream power, shear stress and flow area have to be considered to draw conclusions about the minimum morphological spatial demand. Keeping this in mind hydraulic parameters can be used to asses the minimum morphological spatial demand during floods, which should be incorporated in future hazard zone plans and in the planning of the river corridor (Piégay et al., 2005).

\section{Conclusions}

Using different scales enabled correlation of hydraulic parameters with morphological changes (increase of river width) during flood hazards. A large variance of width changes during the floods of 2005 was found for 5 alpine gravel bed rivers. Especially rivers with smaller cross sections before the flood showed the largest width ratios. This finding is also supported by the results of the analysis of the flow area. As flow area decreases, stress on the river banks increases, leading to a higher width ratio class. The significant correlation of the width changes and specific stream power confirms that the specific stream power is a reasonable predictor for river width changes during extreme floods at the reach and sub reach scale and can be used as a screening tool for width changes during extreme floods. The maximum width ratio $\left(R_{\mathrm{W}}\right)$ is increasing if it is scaled from the reach $\left(R_{\mathrm{w}}=3.5\right)$, sub reach $\left(R_{\mathrm{W}}=6.4\right)$ to the local scale $\left(R_{\mathrm{W}}=19.5\right)$. Further mean width ratios on the reach scale can be used as the lower limit for the minimum morphological spatial demand for rivers during extreme floods and can be assessed based on the mean specific stream power.

Incorporating hydraulic data like the specific stream power, shear stress as well as the flow area in flood risk assessment allows to estimate the minimum morphological spatial demand regarding morphological aspects at the local scale. These findings endorse the consideration of the minimum morphological spatial demand of rivers in hazard zone plans. Considering a minimal distance to the river banks, where no buildings or infrastructure is allowed, would significantly reduce the damage potential due to erosion during extreme floods.

Acknowledgements. The authors would like to thank Beatrice Wagner and Gerhard Breitenbaumer for supportive work and the Federal Ministry of Agriculture, Forestry, Environment and Water Management, Division Flood Control Management, and the Government of Carinthia for funding the project. Provision of hydrodynamic numerical models and data by the States of Tyrol and Vorarlberg is also gratefully acknowledged. Further the constructive comments of the reviewers are appreciated.
Edited by: R. Lasaponara

Reviewed by: two anonymous referees

\section{References}

Astrade, L. and Bravard, J. P.: Energy gradient and geomorphological processes along a river influenced by neotectonics (the Saone river, France), Geodin. Acta, 12, 1-10, 1999.

Bagnold, R. A.: Bed load transport by natural rivers, Water Resour. Res., 13, 303-312, 1977.

Barker, D. M., Lawler, D. M., Knight, D. W., Morris, D. G., Davies, H. N., and Stewart, E. J.: Longitudinal distributions of river flood power: the combined automated flood, elevation and stream power (CAFES) methodology, Earth Surf. Proc. Land., 34, 280290, 2009.

Benito, G.: Energy expentidture and geomorphic work of the cataclysmic Missoula flooding in the Columbia River gorge, Earth Surf. Proc. Land., 22, 457-472, 1997.

Bertoldi, W., Zanoni, L., and Tubino, M.: Assessment of morphological changes induced by flow and flood pulses in a gravel bed braided river: The Tagliamento River (Italy), Geomorphology, 114(3), 348-360, 2010.

Bledsoe, B. P. and Watson, C. C.: Logistic analysis of channel pattern thresholds: Meandering, braiding, and incising, Geomorphology, 38, 281-300, 2001.

Breitenbaumer, G.: Testing the applicability of the specific stream power tool in river morphology - with a primary focus on Austrian river data sets BOKU Vienna, Diploma thesis, Institute of Water Management, Hydrology and Hydraulic Engineering, Vienna, 2008.

Brooks, G. R. and Lawrence, D. E.: The drainage of the Lake Ha!Ha! reservoir and downstream geomorphic impacts along Ha!Ha! River, Saguenay area, Quebec, Canada, Geomorphology, 28, 141-168, 1999.

Cenderelli, D. A. and Wohl, E.: Peak discharge estimates of glaciallake outburst floods and "normal" climatic floods in the Mount Everest region, Nepal, Geomorphology, 40, 57-90, 2001.

Cenderelli, D. A. and Wohl, E.: Flow hydraulics and geomorphic effects of glacial-lake outburst floods in the Mount Everest region, Nepal, Earth Surf. Proc. Land., 28, 385-407, 2003a.

Cenderelli, D. A. and Wohl, E. E.: Flow hydraulics and geomorphic effects of glacial-lake outburst floods in the Mount Everest region, Nepal, Earth Surf. Proc. Land., 28, 385-407, 2003b.

Church, M.: Geomorphic thresholds in riverine landscapes, Freshwater Biol., 47, 541-557, 2002.

Eaton, B. C. and Lapointe, M. F.: Effects of large floods on sediment transport and reach morphology in the cobble-bed Sainte Marguerite River, Geomorphology, 40, 291-309, 2001.

Eaton, B. C., Church, M. A., and Millar, R. G.: Rational regime model of alluvial channel morphology and response, Earth Surf. Proc. Land., 29, 511-529, 2004.

Edegger, S.: Visualisierung von qualitativen Daten in Kartenform: Raumtypisierung, Modellierung und kartographische Darstellung von Chancen-Risiko-Bewertungen alternativer Zukunftsszenarien für drei exemplarische Raumtypen, Diplomarbeit am Institut für Geographie und Regionalforschung, Universität Wien, April 2008 (in German).

FOWG, FOWL, FOA, and FOSP: Space for rivers, Swiss, 2000. 
Gilvear, D.: Fluvial geomorphology and river engineering: future roles utilizing a fluvial hydrosystems framework, Geomorphology 31, 229-245, 1999.

Habersack, H. and Moser, A.: Documentation of the floods in 2002 in Austria, BOKU - University of Natural Resources and Applied Life Sciences, Vienna, ZENAR - Center for Natural Hazards and Risk Management, Federal Ministry of Agriculture, Forestry, Environment and Water Management, Vienna, Documentation, 185 pp., 2003.

Habersack, H., Bürgel, J., and Kanonier, A.: FloodRisk II - Deepening and crosslinking of trend setting strategies for integrative flood management Federal Ministry of Agriculture, Forestry, Environment and Water Management, Wien, Synthesebericht, 1259, 2009.

Habersack, H. M.: The river-scaling concept (RSC): a basis for ecological assessments, Hydrobiologia, 422-423, 49-60, 2000.

Hauer, C. and Habersack, H.: Morphodynamics of a 1000-year flood in the Kamp River, Austria, and impacts on floodplain morphology, Earth Surf. Proc. Land., 34, 654-682, 2009.

Höfle, B., Vetter, M., Pfeifer, N., Mandlburger, G., and Stötter, J.: Water surface mapping from airborne laser scanning using signal intensity and elevation data, Earth Surf. Proc. Land., 34, 16351649, doi:10.1002/esp.1853, 2009.

Hooke, J. M.: Temporal variations in fluvial processes on an active meandering river over a 20-year period, Geomorphology, 100, 3-13, 2008.

Hydrographic Service: Hydrological data 08/2005 of the Bregenzerach, Lech, Trisanna, Rosanna and Alfenz Rivers, 2005.

Kale, V. S.: Geomorphic effectiveness of extraordinary floods on three large rivers of the Indian Peninsula, Geomorphology, 85, 306-316, 2007.

Knighton, A. D.: Downstream variation in stream power, Geomorphology, 29, 293-306, 1999.

Kochel, R. C.: Geomorphic impact of large floods: Review and new perspectives on magnitude and frequency, in: Flood Geomorphology, edited by: Baker, V. R., Kochel, R. C., and Patton, P. C., John Wiley and Sons, New York, 169-186, 1988.

Lapointe, M. F., Secretan, Y., Driscoll, S. N., Bergeron, N., and Leclerc, M.: Response of the Ha! Ha! River to the flood of July 1996 in the Saguenay Region of Quebec: Large-scale avulsion in a glaciated valley, Water Resour. Res., 34, 2383-2392, 1998.

Lebensministerium: Hochwasser 2005 - Ereignisdokumentation, Teilbericht des Hydrographischen Dienstes, Austria, 2006 (in German).

Magilligan, F. J.: Thresholds and the spatial variability of flood power during extreme floods, Geomorphology, 5, 373-390, 1992a.

Magilligan, F. J.: Thresholds and the spatial variability of flood power during extreme floods, Geomorphology 5, 373-390, 1992b.

Magilligan, F. J., Phillips, J. D., James, L. A., and Gomez, B.: Geomorphic and sedimentological controls of the effectiveness of an extreme flood, J. Geol., 106, 87-96, 1998.

Miller, A. C.: Flood hydrology and geomorphic effectiveness in the central Appalachians, Earth Surf. Proc. Land., 15, 119-134, 1990.

Mount, N. J., Louis, J., Teeuw, R. M., Zukowskyj, P. M., and Stott, T.: Estimation of error in bankfull width comparisons from temporally sequenced raw and corrected aerial photographs,
Geomorphology, 56, 65-77, 2003.

Muhar, S., Poppe, M., Egger, G., Schmutz, S., and Melcher, A.: Flusslandschaften Österreichs - Ausweisung von Flusslandschaftstypen anhand des Naturraums, der Fischfauna und der Auenvegetation, Bundesministerium für Bildung, Wissenschaft und Kultur, Wien, 2004 (in German).

Neuhold, C., Stanzel, P., and Nachtnebel, H. P.: Incorporating river morphological changes to flood risk assessment: uncertainties, methodology and application, Nat. Hazards Earth Syst. Sci., 9, 789-799, doi:10.5194/nhess-9-789-2009, 2009.

ÖROK (sterreichische Raumordnungskonferenz): Zwölfter Raumordnungsbericht, Wien, 2005.

Ortega, J. A. and Heydt, G. G.: Geomorphological and sedimentological analysis of flash-flood deposits. The case of the 1997 Rivillas flood (Spain), Geomorphology, 112, 1-14, 2009.

Papa, M., Egashira, S., and Itoh, T.: Critical conditions of bed sediment entrainment due to debris flow, Nat. Hazards Earth Syst. Sci., 4, 469-474, doi:10.5194/nhess-4-469-2004, 2004.

Phillips, J. D.: Geomorphic impacts of flash flooding in a forested headwater basin, J. Hydrol., 269, 236-250, 2002.

Piégay, H., Darby, E. S., Mosselman, E., and Surian, N.: A review of techniques available for delimiting the erodible river corridor: A sustainable approach to managing bank erosion, River Res. Appl., 21, 773-789, 2005.

Plate, E. J.: Flood risk and flood management, J. Hydrol., 267, 2$11,2002$.

Reinfelds, I.: Reconstruction of changes in bankfull width : A comparison of surveyed cross-sections and aerial photography, Appl. Geogr., 17, 203-213, 1997.

Stacey, M. and Rutherfurd, I.: Testing specific stream power thresholds of channel stability with GIS, 5th Annual Australian Stream Management Conference, Albury, Australia, 384-389, 2007.

State of Vorarlberg (Department of Water Management): Hydraulic model data of the Bregenzerach River, unpublished data, 2007.

State of Tyrol (Department of Water Management): Hydraulic model data of the Lech River, unpublished data, 2007.

Wohl, E.: Review of effects of large floods in resistant-boundary channels, in: Developments in Earth Surface Processes, edited by: Habersack, H., Piégay, H., and Rinaldi, M., Elsevier, 181211, 2007.

Wolman, M. G. and Gerson, R.: Relative scales of time and effectiveness of climate in watershed geomorphology, Earth Surf. Proc. Land., 3, 189-208, 1978.

Yin, H. and Li, C.: Human impact on floods and flood disasters on the Yangtze river, Geomorphology, 41, 105-109, 2001.

Zhang, Q., Shi, Y., and Xiong, M.: Geometric properties of river cross sections and associated hydrodynamic implications in Wuhan-Jiujiang river reach, the Yangtze River, J. Geogr. Sci., 19, 58-66, 2009.

Zielinski, T.: Catastrophic flood effects in alpine/foothill fluvial system (a case study from the Sudetes Mts, SW Poland), Geomorphology, 54, 293-306, 2003.

Zimmermann, A. and Church, M.: Channel morphology, gradient profiles and bed stresses during flood in a step-pool channel, Geomorphology, 40, 311-327, 2001. 